\title{
Heat Recovery from a PtSNG Plant Coupled with Wind Energy
}

\author{
Daniele Candelaresi *(D), Linda Moretti, Alessandra Perna and Giuseppe Spazzafumo
}

Citation: Candelaresi, D.; Moretti, L.; Perna, A.; Spazzafumo, G. Heat Recovery from a PtSNG Plant Coupled with Wind Energy. Energies 2021, 14, 7660. https://doi.org/ $10.3390 /$ en14227660

Academic Editor: Andrea De Pascale

Received: 15 October 2021

Accepted: 12 November 2021

Published: 16 November 2021

Publisher's Note: MDPI stays neutral with regard to jurisdictional claims in published maps and institutional affiliations.

Copyright: (c) 2021 by the authors. Licensee MDPI, Basel, Switzerland. This article is an open access article distributed under the terms and conditions of the Creative Commons Attribution (CC BY) license (https:// creativecommons.org/licenses/by/ $4.0 /)$.
Department of Civil and Mechanical Engineering, University of Cassino and Southern Lazio, Cassino 03043, Italy; linda.moretti@unicas.it (L.M.); perna@unicas.it (A.P.); spazzafumo@unicas.it (G.S.)

* Correspondence: daniele.candelaresi@unicas.it

\begin{abstract}
Power to substitute natural gas (PtSNG) is a promising technology to store intermittent renewable electricity as synthetic fuel. Power surplus on the electric grid is converted to hydrogen via water electrolysis and then to SNG via $\mathrm{CO}_{2}$ methanation. The SNG produced can be directly injected into the natural gas infrastructure for long-term and large-scale energy storage. Because of the fluctuating behaviour of the input energy source, the overall annual plant efficiency and SNG production are affected by the plant operation time and the standby strategy chosen. The re-use of internal (waste) heat for satisfying the energy requirements during critical moments can be crucial to achieving high annual efficiencies. In this study, the heat recovery from a PtSNG plant coupled with wind energy, based on proton exchange membrane electrolysis, adiabatic fixed bed methanation and membrane technology for SNG upgrading, is investigated. The proposed thermal recovery strategy involves the waste heat available from the methanation unit during the operation hours being accumulated by means of a two-tanks diathermic oil circuit. The stored heat is used to compensate for the heat losses of methanation reactors, during the hot-standby state. Two options to maintain the reactors at operating temperature have been assessed. The first requires that the diathermic oil transfers heat to a hydrogen stream, which is used to flush the reactors in order to guarantee the hot-standby conditions. The second option entails that the stored heat being recovered for electricity production through an Organic Rankine Cycle. The electricity produced is used to compensate the reactors heat losses by using electrical trace heating during the hot-standby hours, as well as to supply energy to ancillary equipment. The aim of the paper is to evaluate the technical feasibility of the proposed heat recovery strategies and how they impact on the annual plant performances. The results showed that the annual efficiencies on an LHV basis were found to be $44.0 \%$ and $44.3 \%$ for the thermal storage and electrical storage configurations, respectively.
\end{abstract}

Keywords: power to substitute natural gas (PtSNG); methanation; heat recovery; hot-standby; cold-standby; annual performance

\section{Background and Scope}

Renewable energy sources (RESs) are the keystone of the energy policy of the European Union (EU) to fulfil the target of a carbon neutral economy by 2050 [1]. According to the European Directive 2018/2001 on the promotion of the use of energy from renewable sources, Member States shall collectively ensure that the share of energy from RESs in the EU's gross final consumption of energy is at least 32\% by 2030 [2]. Such a goal has been recently judged as not ambitious enough. Therefore, the European Commission has started to review the old regulatory packages relating to climate change. It is expected that the new renewable energy directive will set an increased target, in which $40 \%$ of the European final energy consumption should come from RESs by 2030 [3]. This goal involves increasing the share of non-programmable RESs in electricity generation, especially wind energy. The International Energy Agency expects wind energy to be the main energy source used for producing electricity in 2027 [4]. Wind power growth will be driven by future improvement in the design and management of wind farms $[5,6]$. 
However, the effective integration of wind energy in the power system can only be reached by developing suitable storage technologies able to stabilise the electricity grids and increase flexibility. Owing to its intermittent and random nature, power production from non-programmable RESs generates critical issues in the balance between energy supply and demand, especially during overgeneration periods.

Power to Substitute Natural Gas (PtSNG) is one of the most promising storage technologies to support RESs integration in the energy system [7]. Exploiting the natural gas (NG) transmission and distribution networks, as well as the storage features of the existing NG infrastructure, the substitute natural gas (SNG) produced from surplus renewable energy can be injected into the NG pipeline system, allowing the storage of large amounts of energy for long-term periods, thus offering balancing and regulation services to the electricity grid. However, large-scale development of PtSNG technology is currently limited due to the relative low efficiency and high costs [8,9]. Both aspects significantly depend on the employment of the by-products derived from the PtSNG process (e.g., oxygen, waste heat) [8].

In this sense, the use of waste heat from the methanation process is crucial to increase the efficiency of the PtSNG process chain $[8,10,11]$. The $\mathrm{CO}_{2}$ methanation reaction is a highly exothermic catalytic process operating typically at temperatures between $150{ }^{\circ} \mathrm{C}$ and $550{ }^{\circ} \mathrm{C}$ depending on the catalyst used [12]. The reaction heat released by the methanation of $1 \mathrm{~mol}$ of $\mathrm{CO}_{2}$ is about equal to $165.1 \mathrm{~kJ}$ [13]. Furthermore, the outgoing SNG from the methanation process requires dehydration and cooling from an elevated temperature (i.e., 300-700 ${ }^{\circ} \mathrm{C}$, depending on the reactor concept [8]) to be injected into the NG infrastructure. These processes represent sources of thermal energy at a medium-high temperature level that can be exploited to reduce the overall PtSNG system energy input, and thus increase its efficiency.

Several studies have investigated heat integration as an effective option for improving the energy efficiency of PtSNG technology.

Schaaf et al. [11] showed that the heat generated due to the exothermic reactions involved in the methanation process can be used for heating up the feed of reactors and producing electricity for plant operation, completely covering the energy demand of the plant. Moreover, the authors suggest that the excess heat not recovered internally can be used in various ways (e.g., district heating, power generation via steam turbine, etc.).

Buchholz et al. [14] evaluated the techno-economic feasibility of a PtSNG process integrated with a Lignite-fired Power Plant (LPP). The presented concept entails the thermal energy available from the methanation process being recovered by steam production and used in the LPP and the $\mathrm{CO}_{2}$ absorption unit, obtaining an efficiency of the PtSNG system of approximately $54 \%$.

Anghilante and Lefebvre [15] investigated the feasibility of thermal integration between the high-temperature electrolysis and three-phase methanation reactor processes. The overall plant efficiency obtained is about $68 \%$, which is significantly higher than the values found by other authors in the literature.

Giglio et al. [16] analysed the energy performance of an integrated system of hightemperature electrolysis and SNG production via the methanation process. In detail, two different plant layouts based on steam electrolysis and co-electrolysis of steam and $\mathrm{CO}_{2}$ in a solid oxide electrolysis cell (SOEC) plant were assessed. In order to minimise the thermal energy demand of the plant, the authors performed a thermal integration, supposing that the waste heat from methanation is exploited for pre-heating the SOEC reactants. The results showed that the overall plant efficiency is $76.0 \%$ and $81.4 \%$, respectively, for the plant based on steam electrolysis and co-electrolysis. In addition, both plants are characterised by an external energy demand of about $160 \mathrm{~kW}$ each against an overall required thermal input of 3 and $4 \mathrm{MW}_{\text {th }}$ for steam electrolysis and co-electrolysis, respectively.

Gruber et al. [17] presented the experimental results of a pressurised SOEC system thermally integrated with a $\mathrm{CO}_{2}$ methanation module. The evidence from the experiments 
revealed that the PtSNG process could be characterised by an overall efficiency $>82 \%$ if the re-use of waste heat from the $\mathrm{CO}_{2}$ methanation process is performed.

Frank et al. [10] demonstrated that the highest overall system efficiency that can be reached is as low as $54.3 \%$ if no excess heat is used at all, whereas the highest system efficiency with comprehensive usage of excess heat is $85.9 \%$.

Chauvy et al. [18] proposed a PtSNG plant integrated with an advanced $\mathrm{CO}_{2}$ capture process by an optimised heat recovery system, which allows the production of complementary electricity, thus reducing the electrical demand of the integrated process. The results showed that the thermal integration led to an overall system efficiency equal to $72.6 \%$.

In a previous work [19], the authors evaluated the energy storage potential and the technical feasibility of the PtSNG concept to store intermittent renewable sources. For this aim, different plant sizes (i.e., $1 \mathrm{MW}, 3 \mathrm{MW}$ and $6 \mathrm{MW}$ ) were defined and investigated. The analysis results indicated that the annual overall plant efficiency decreases as plant size increases (i.e., from $43.7 \%$ to $41.6 \%$ ) due to the growing impact of the energy required to balance the heat losses in the hot-standby mode (i.e., the standby period increases from $2713 \mathrm{~h}$ to $4590 \mathrm{~h}$ ). However, the plant efficiencies were evaluated without taking into account thermal energy management.

Owing to the fluctuating behaviour of the input energy source, the operation of the PtSNG plant sub-systems (i.e., electrolysis and methanation units) is characterised by frequent shutdowns, and consequently by frequent changeovers of state (i.e., cold-standby, hot-standby and production with different loads) $[10,19,20]$. On the basis of the plant management strategy, the energy consumption required to restart the SNG production from the cold-standby state, as well as the energy consumption necessary for keeping the sub-systems in a hot-standby state, could significantly increase the energy input required and therefore negatively affect the annual performance of PtSNG plants.

In this paper, a novel thermal management strategy for a PtSNG plant coupled with an RES facility is presented. The concept involves employing the waste heat produced by the methanation process to assure the hot-standby conditions of the methanation unit itself, as well as to fulfil the ancillary equipment energy demand. The proposed strategy entails that the waste heat is accumulated by means of a two-tanks diathermic oil circuit during the operation hours of the methanation unit, and then it is used to compensate for the heat losses of methanation reactors during the hot-standby state. In particular, two different systems to maintain the reactors at operating temperature have been considered. The aim of this paper is to evaluate the technical feasibility of the proposed heat recovery strategies and how they impact on the annual plant performances.

\section{PtSNG Plant Description}

The PtSNG plant, shown in Figure 1, is directly coupled with a 12 MW wind farm and is sized for $1 \mathrm{MW}$ of electric power input. It consists of four sections: (i) The hydrogen generation unit based on the proton exchange membrane (PEM) electrolyser, (ii) the methanation unit based on the fixed-bed reactors technology, (iii) the $\mathrm{H}_{2}$ storage unit, in which gaseous hydrogen is stored in pressurised vessels and (iv) the SNG upgrading unit based on the membrane technologies.

The demineralised water (1) is pumped and heated to the operative pressure and temperature of the PEM electrolysis unit where $\mathrm{O}_{2}$ and $\mathrm{H}_{2}$ are produced. On the basis of a specific control strategy, $\mathrm{H}_{2}$ generated via electrolysis (stream 5) can be partially or entirely sent to the methanation unit (6) and/or to the intercooled compressor C1 (8) to increase the pressure up to the maximum storage pressure. The compressed $\mathrm{H}_{2}(9)$ is stored in high-pressure tanks. The $\mathrm{H}_{2}$ streams from the electrolysis unit and/or storage unit are mixed with the $\mathrm{CO}_{2}$ stream (13) from the $\mathrm{CO}_{2}$ storage unit. The $\mathrm{CO}_{2}$ is assumed to be always available for the PtSNG plant (i.e., supplied by sequestration from other power plants or industrial processes) at the storage pressure of $200 \mathrm{bar}$. 


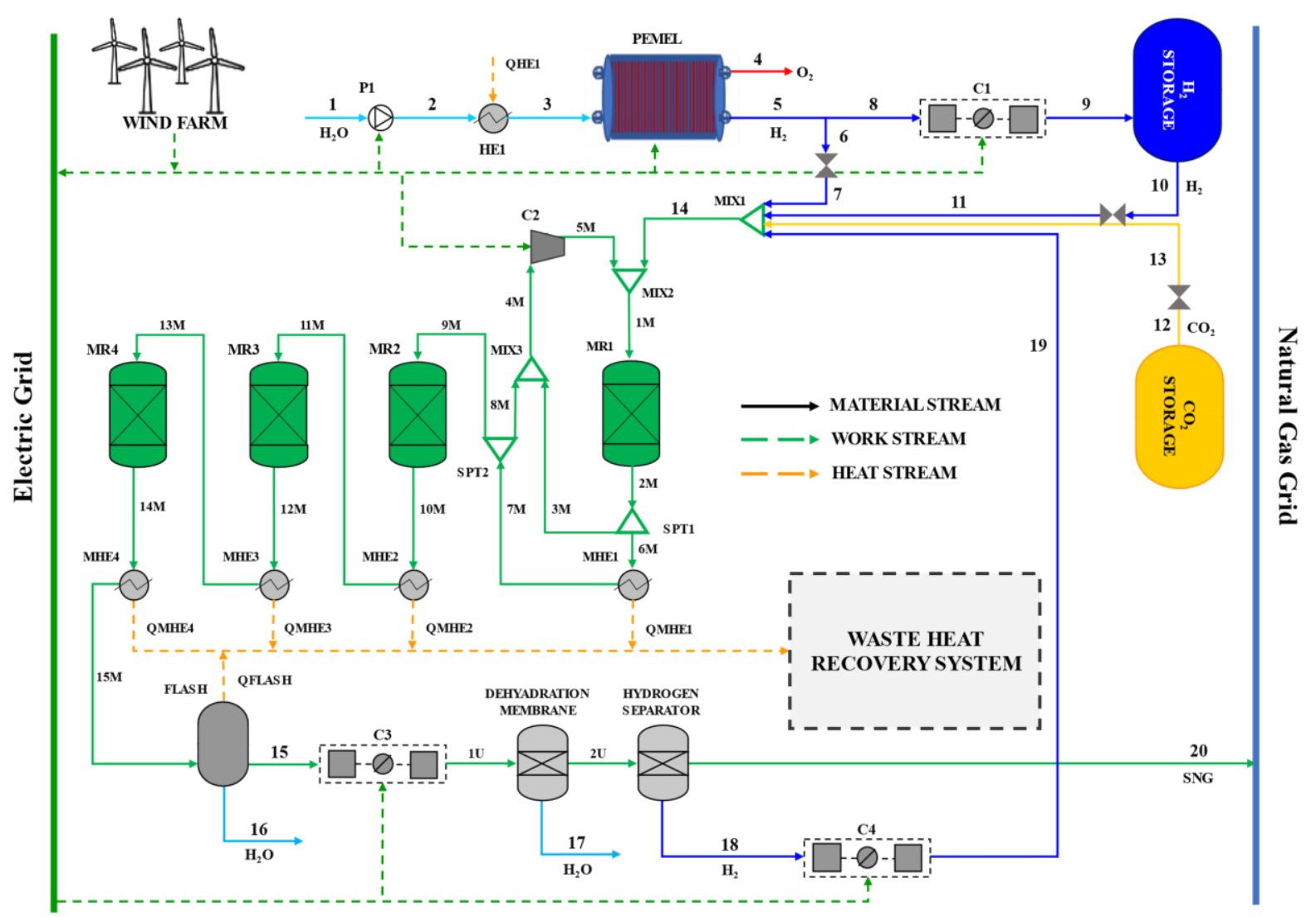

Figure 1. PtSNG plant layout.

The methanation unit consists of four adiabatic fixed-bed reactors (MR1, MR2, MR3, MR4) connected in series with intermediate gas cooling (heat exchangers MHE1, MHE2, MHE3) for assuring the fixed inlet reactors temperatures. The $\mathrm{H}_{2}$ and the $\mathrm{CO}_{2}$ entering the methanation unit are mixed with the hydrogen (19) from the SNG upgrading unit and then preheated to the inlet temperature of the methanation reactor MR1 $\left(300^{\circ} \mathrm{C}\right)$. This preheating is performed by mixing the reactant flow (14) with hot streams from the MR1 and MHE1 defined by specified recirculation ratios (stream $3 \mathrm{M}$ at the splitter SPT1 and stream $8 \mathrm{M}$ at the splitter SPT2). Thus, the syngas (9M) sent to the MR2 reactor is a fraction of the product gases leaving the first methanation reactor. In the following reactors (MR3 and MR4), $\mathrm{CO}_{2}$ hydrogenation is led at decreasing temperature levels, reaching the conversion of $94 \%$ at the exit of the last methanation reactor. During the methanation process, a large amount of water is produced, so the raw SNG (14M) is cooled in the heat exchanger MHE4 and sent to the flash vapor-liquid separator (FLASH) for water removal. In order to meet the required grid specifications, the SNG (15) is further upgraded by means of a dehydration membrane (a commercial Pebax ${ }^{\circledR}$-based membrane [18]) to eliminate the residual moisture to comply with the $\mathrm{H}_{2} \mathrm{O}$ dew point requirements of the pipelines and an $\mathrm{H}_{2}$ separation membrane (polysolfone-based membrane).

The quality of the SNG exiting the upgrading section (20) satisfies the current pipeline specifications effective in various European countries, as reported in [21], and therefore can be directly injected into the low-medium pressure NG transmission network. If the country-specific pipeline requirements are more stringent, additional $\mathrm{CO}_{2}$ or $\mathrm{H}_{2}$ removal systems should be considered. The hydrogen from the upgrading unit is recycled to the first methanation reactor, as mentioned above.

Finally, the waste heat available from the methanation unit and the flash unit can be usefully recovered in the waste heat recovery system according to concepts that will be described below. 
The PtSNG plant is operated in an input-oriented mode. In order to maximise the operating hours of the plant, a hydrogen storage unit is employed to decouple the $\mathrm{H}_{2}$ generation and the SNG production.

As a management strategy, four operation modes are allowed for the methanation unit: (i) Full load, in which the hydrogen flow rate entering the methanation unit from the storage and/or the electrolyser is equal to the nominal value; (ii) partial load, in which the hydrogen flow rate sent to methanation reactors varies from $40 \%$ to $100 \%$ of the nominal value, according to the specified minimum and maximum hydrogen storage pressures; (iii) hot-standby mode, in which the reactors are kept at the minimum operating temperature of the catalysts to allow a quick restart; and (iv) cold-standby mode, in which no carbon dioxide and hydrogen feed the methanation unit. Even if a restart from coldstandby requires more energy than that required to maintain the hot-standby, this operation mode can be convenient when the number of hours from the shut-down to the restart is high. The parameter that controls the start of the plant and the operation modes of the methanation unit is the hydrogen storage pressure, which follows the control strategy widely described in [19].

The mass and energy balances of the PtSNG plant in steady-state conditions as well as the annual performance of the plant are performed by applying the thermochemical and electrochemical model (in an Aspen Plus environment) and the dynamic model (in a MATLAB environment) developed and described in [19].

The thermochemical and electrochemical model consists of sub-models for each plant section; in this study, the sub-model of the methanation unit, modified by considering the kinetics of the process, is described in Appendix A.

The dynamic model based on the annual hourly energy input (the wind energy supplied to the plant) and on the storage control strategy allows for forecasting the annual operation time (full and partial load hours, standby hours) and the annual performances (SNG production, energy consumption, efficiency) of the PtSNG plant.

\section{Heat Recovery Management}

The heat recovery management is based on the valorisation of the waste heat, generated during the plant operation in the methanation unit, to self-sustain, from an energetic point of view, the standby conditions. To this end, two heat recovery configurations based on different heat recovery concepts are proposed and investigated. In both configurations, the recovery of the waste heat coming from the methanation unit is performed by means of a heat transfer fluid (i.e., diathermic oil) stored in insulated tanks for thermal energy storage.

Figure 2 shows the conceptual schemes of the two heat recovery systems.

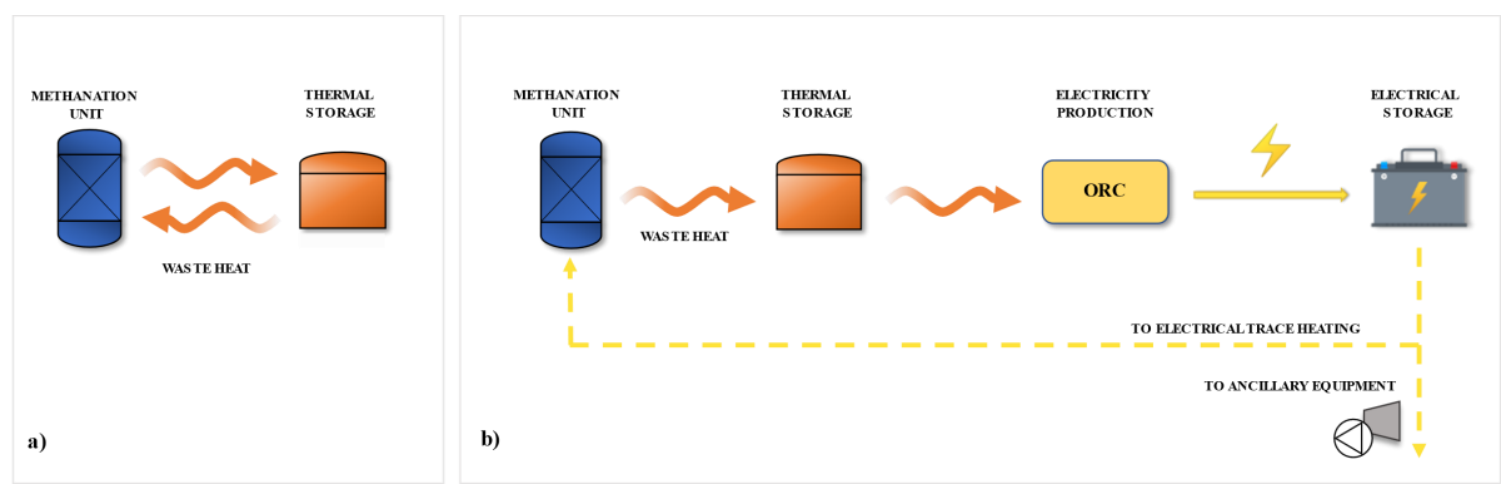

Figure 2. Conceptual schemes and energy flows of the two proposed waste heat recovery systems: (a) Thermal storage; (b) electrical storage. 
In the first one (thermal storage configuration, Figure 2a, the stored thermal energy is used to satisfy the thermal energy demand of the reactors during the standby periods by means of a thermal carrier.

In the second one (electrical storage configuration, Figure $2 b$, the stored thermal energy is used to produce electricity by means of an Organic Rankine Cycle (ORC). This electrical energy is stored in batteries, and it is used to meet the energy requirements of the electrical trace heating system of the methanation unit during the standby periods. In this case, the stored electric energy is also used to satisfy the ancillary equipment electricity demand.

\subsection{Thermal Storage}

In the thermal storage system, the waste heat is recovered and stored by means of a two-tank diathermic oil circuit; the stored thermal energy is supplied, when required, to the methanation reactors by means of a thermal carrier. Hydrogen is used as a thermal carrier because it removes the residual carbon dioxide preventing catalyst deactivation. Figure 3 shows the layout of the thermal storage configuration.

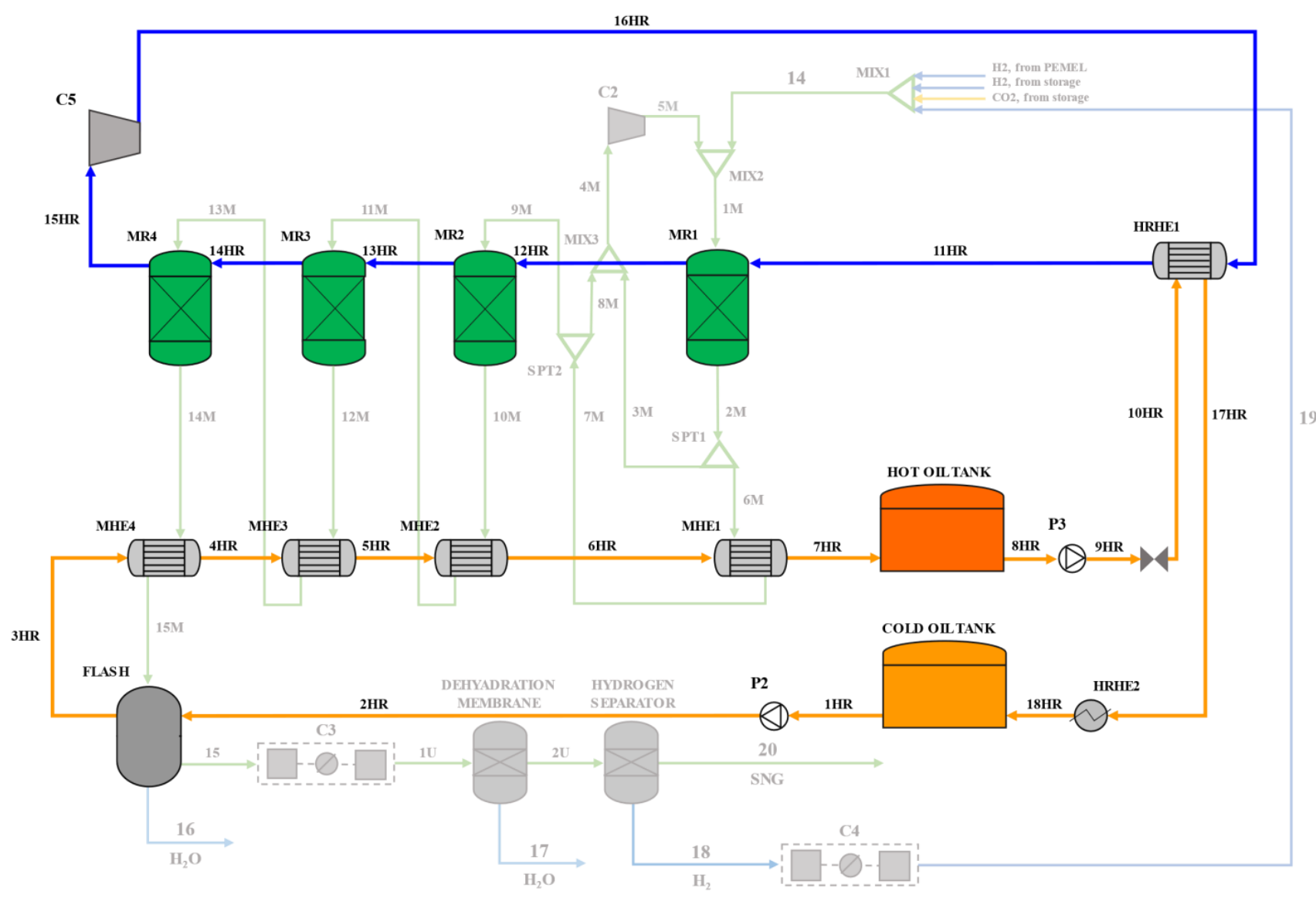

Figure 3. Schematic diagram of thermal storage system.

During the plant operation, the diathermic oil (stream 1HR) from the cold oil tank is pushed (2HR) by pump P2 and sent to the methanation unit for heat recovery (heat exchangers MHE1, MHE2, MHE3, MHE4 and the FLASH unit) in such a way to minimise the temperature gradients and optimise the heat transfer efficiencies; at the exit of the MHE1, the hot diathermic oil (7HR) is stored in the hot oil tank.

When the reactors need to be heated, the diathermic oil from the hot oil tank is sent to the heat recovery heat exchanger (HRHE1) for heating the hydrogen used as a thermal carrier. The diathermic oil leaving the HRHE1 is cooled down in the HRHE2 to the storage 
temperature of the cold oil tank. This cooling heat can be further recovered for external or internal use.

The thermal power transferred by the hot hydrogen allows one to compensate for the thermal losses in all the reactors and to maintain the temperature of the catalysts within the activation range. The cold $\mathrm{H}_{2}(15 \mathrm{HR})$ is recovered downstream from the last reactor MR4 to be recirculated again.

\subsection{Electrical Storage}

In the electrical storage system, the waste heat is recovered by means of a two-tank diathermic oil circuit (they are conceived as buffer tanks) and the stored thermal energy is used to generate electricity via an ORC. The oil tanks allow one to ensure continuous and stable operation of the ORC by decoupling the heat storage (which depends on the methanation unit operation) from the electricity production. The produced electricity stored in batteries is supplied, when required, to the electrical trace heating system of the methanation unit and used for ancillary equipment.

Figure 4 depicts the electrical storage configuration.

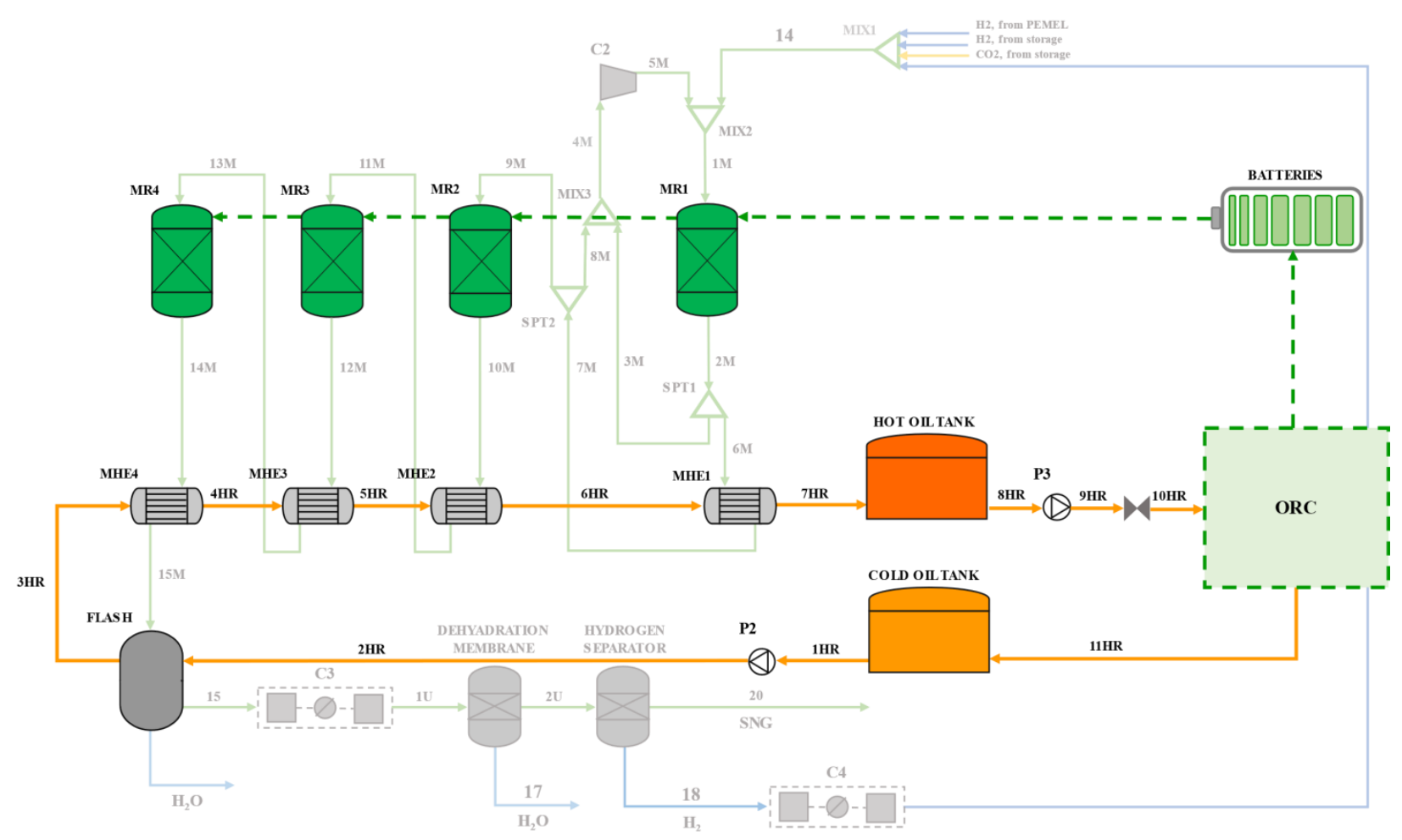

Figure 4. Schematic diagram of electrical storage system.

The diathermic oil circuit works as described in the thermal storage configuration. When the hot oil tank is full, the diathermic oil (stream 8HR) is sent to the ORC unit to supply the thermal power required by the ORC cycle. The returning cold oil (stream 11HR) is then stored in the cold oil tank.

Referring to the ORC power unit, by taking into account the heat sources temperatures as well as additional features (low toxicity, low global warming potential and ozone depletion potential, good compatibility and chemical stability in operation with other materials, etc.), iso-butane (R600a) is selected as the working fluid. In Figure 5, the functional scheme of the ORC power unit is shown. 


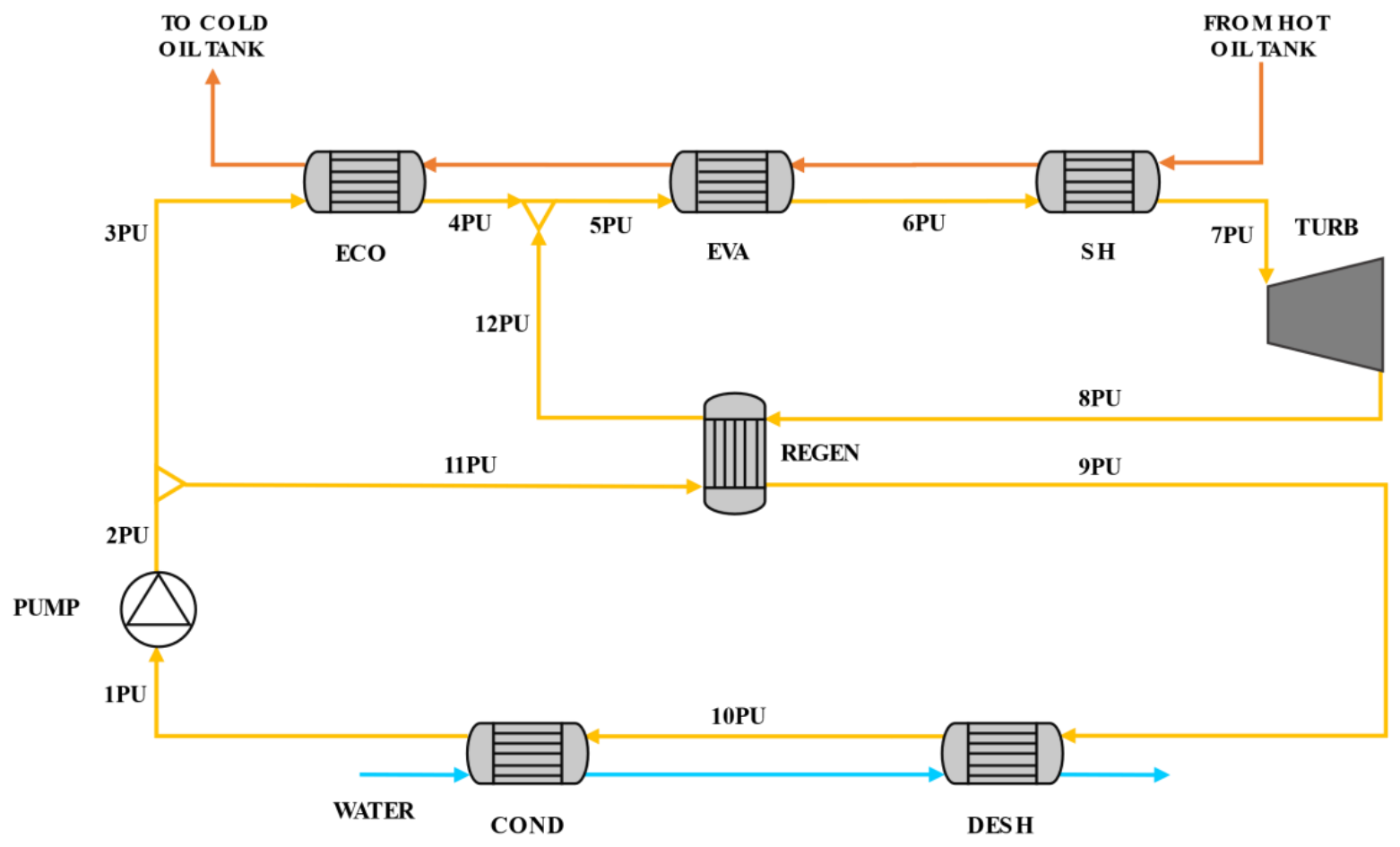

Figure 5. Functional scheme of the ORC.

The organic fluid (stream 1PU, in Power Unit) leaving the condenser (COND) is pressurised up to the maximum pressure of the cycle (2PU). In order to optimise the use of the heat from the thermal storage and the internally available heat, it is split in two streams, $3 \mathrm{PU}$ and 11PU. The first one (3PU) is sent to the economiser (ECO) where it is pre-heated to the saturation condition (4PU) by the diathermic oil, while the second one is pre-heated (12PU) in the regenerator (REGEN) by the 8PU stream that exits the scroll expander, which is still in a superheated condition (the iso-butane is a dry fluid). The streams 4PU and 12PU are mixed and the result is vaporised and superheated to the turbine inlet temperature by diathermic oil. The superheated vapour (7PU) expands in the scroll expander (TURB) down to the condenser pressure. The desuperheating of the iso-butane (9PU) is completed in the desuperheater heat exchanger (DESH) where it is cooled down to its dew-point temperature (10PU) and finally condensed in the condenser (COND).

\section{Heat Recovery System Sizing Criteria}

Both proposed heat recovery configurations are sized for assuring the thermal energy needed to maintain the hot-standby conditions of the methanation unit and the thermal energy needed for the cold restart.

The sizing procedure of the heat recovery systems is performed through the evaluation of (i) the thermal energy that can be recovered from the methanation unit (QMHE1, QMHE2, QMHE3, QMHE4) and the flash unit (QMHE5) and the temperatures at which they are available; (ii) the thermal energy required by the methanation unit in the hot-standby status and that required for the restart after a cold-standby; (iii) the optimal combination between the number of hot-standby hours and that of cold-standby.

The thermal energy recoverable from the methanation unit and the flash unit as well as the temperatures at which it is available is assessed by the mass and energy balance of the plant.

The thermal energy needed to maintain the hot-standby status (i.e., to maintain the reactors at the catalysts activation temperature) as well as that needed to warmup the reactors after a cold-standby (the thermal energy consumption to warm-up the reactors from ambient temperature to the catalysts activation temperature) has been calculated by considering convective and conductive heat transfer mechanisms. 
The standby hours are calculated by applying the dynamic model. The number of hours of hot-standby and, as a consequence, that of cold-standby, is evaluated by assuming the minimum capacity of the storage devices (the diathermic oil tanks for the thermal energy storage and the batteries for the electric energy storage) able to satisfy the energy requirements and, at the same time, to make the plant economically feasible.

Thus, in order to identify the optimum combination between hot and cold-standby hours, statistical analysis of the plant's standby hours distribution is carried out in terms of the average duration and frequency. It is worth noting that this analysis is site-specific and closely linked to the typical annual wind energy profile of the considered plant, therefore tailor-made considerations would be required for other plants.

\section{Performance Parameters}

The PtSNG plant nominal efficiency is defined as the ratio between the useful output powers (i.e., the chemical power of the SNG) and the input powers. The input powers for the PtSNG plant are represented by the electric power consumption for the electrolyser and the ancillary equipment, namely the hydrogen compressor for hydrogen storage, the blowers for the methanation unit and the raw SNG compressor and the hydrogen compressor for the upgrading unit. The efficiencies are calculated taking into account both the lower heating value (LHV) and the higher heating value (HHV) for the calculation of the chemical powers.

The nominal overall efficiency of the PtSNG plant results in the following equation:

$$
\eta_{P t S N G}=\frac{\Phi_{S N G}}{P_{e l, R E S}+P_{e l, H 2}+P_{e l, M U}+P_{e l, U U}}
$$

In the above equation, $\Phi_{S N G}$ is the chemical power of the generated SNG, $P_{e l, R E S}$ is the wind power supply to the electrolysis unit in alternate current (AC), $P_{e l, H 2}$ is the power consumption of the hydrogen compressor for the $\mathrm{H}_{2}$ storage, $P_{e l, M U}$ is the electric power consumption of recirculation blower in the methanation unit and $P_{e l, U U}$ is the power consumption of the upgrading unit, which includes the power consumption of the SNG compressor and that of the hydrogen compressor downstream from the hydrogen membrane separation. The thermal power available from the methanation unit heat exchangers is not accounted for in this calculation.

Because of the fluctuating behaviour of the input energy source, the nominal efficiencies are not sufficient to evaluate the effectiveness of the plant, but it is necessary to evaluate the annual performance [10]. This is defined as the ratio of the usable system energy output to the overall system energy input (electricity and possibly heat) $[10,22]$. Therefore, the overall annual efficiency of the PtSNG plant is calculated as the nominal efficiency, by replacing the power with the energy (electric or chemical) consumed or generated in one year of operation. However, in this case, the thermal energy required to maintain the plant equipment in hot-standby during the non-production hours, as well as that required to restart the reactors after a cold-standby, should be added as energy input:

$$
\varepsilon_{P t S N G}=\frac{E_{S N G}+E_{H 2, \text { storage }}}{E_{e l, R E S}+E_{e l, H 2}+E_{e l, M U}+E_{e l, U U}+E_{t h, M U, H S}+E_{t h, M U, C S}}
$$

where $E_{t h, M U, H S}$ is the thermal energy required to maintain the methanation reactors in hot-standby during the no-production hours, $E_{t h, M U, C S}$ is the thermal energy required

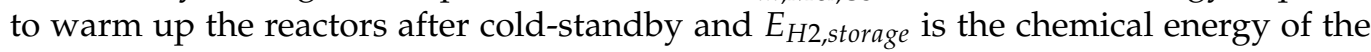
remaining hydrogen in the storage tank. For the purposes of calculating the efficiencies for the proposed configurations, having carried out the heat recovery necessary to make the plant self-sufficient from the point of view of the energy demands of the standby periods, the terms relating to the standby thermal requirements $\left(E_{t h, M U, H S}\right.$ and $\left.E_{t h, M U, C S}\right)$ are considered null. Indeed, these energy requirements are satisfied by re-using internal energy. 


\section{Results and Discussion}

The results of this study are illustrated in the next paragraphs. The mass and energy balances of the 1 MW PtSNG at the full-load condition are discussed in Section 6.1, while the analysis and the results of the proposed heat recovery configurations, thermal storage and electric storage are discussed in Section 6.2. Finally, in Section 6.3, the annual performances are discussed.

\subsection{PtSNG Mass and Energy Balance Results}

Table 1 summarises the main operating parameters of the PtSNG plant. The $1 \mathrm{MW}_{\mathrm{DC}}$ PEM electrolysis unit consists of three stacks with nominal operating conditions, in terms of current density and average cell voltage for each stack, equal to $2.99 \mathrm{~A} / \mathrm{cm}^{2}$ and $2.17 \mathrm{~V}$, respectively. The power consumption of the unit auxiliaries is set to $2.8 \%$ of the rated power. At nominal conditions, the hydrogen generated is equal to $16.8 \mathrm{~kg} / \mathrm{h}$ with a specific energy consumption of $59.6 \mathrm{kWh} / \mathrm{kg}$ of the produced hydrogen. To contain the hydrogen storage tank capacity, the methanation unit is sized for processing the maximum hydrogen flow generated by the electrolysis unit. With this assumption, the decoupling between the dynamics of the electrolysis unit and that of the methanation unit is less effective, but the plant capital costs (based on the storage pressure of 50 bar, the cost is estimated at $375 € / \mathrm{kg}$ [19]) are reduced. Furthermore, the hydrogen storage unit is sized to ensure the full-load operation of the methanation unit for about $6.5 \mathrm{~h}$.

Table 1. Operational data of the PtSNG plant.

\begin{tabular}{|c|c|}
\hline Plant Sections and Components & \\
\hline \multicolumn{2}{|l|}{ PEM Electrolysis Unit } \\
\hline Nominal power (MW) & 1 \\
\hline AC/DC rectifier efficiency $(\%)$ & 95 \\
\hline Stacks number/Cells number per stack & $3 / 50$ \\
\hline Active cell area $\left(\mathrm{cm}^{2}\right)$ & 1000 \\
\hline Cell pressure/temperature $\left(\mathrm{bar} /{ }^{\circ} \mathrm{C}\right)$ & $20 / 55$ \\
\hline Water utilization factor, UF & 0.45 \\
\hline $\begin{array}{c}\text { Current density }\left(\mathrm{A} / \mathrm{cm}^{2}\right) @ \text { Average cell } \\
\text { voltage }(\mathrm{V}) \text { at rated power }\end{array}$ & 2.17 \\
\hline Auxiliaries (\% of rated power) & 2.8 \\
\hline \multicolumn{2}{|l|}{$\mathrm{H}_{2}$ Compressor $(\mathrm{C} 1)$} \\
\hline Pressure ratio & 2.25 \\
\hline Isentropic efficiency (\%) & 70 \\
\hline \multicolumn{2}{|l|}{$\mathrm{H}_{2}$ Storage Unit } \\
\hline Maximum Storage pressure (bar) & 45 \\
\hline Minimum Storage pressure (bar) & 22 \\
\hline Storage temperature $\left({ }^{\circ} \mathrm{C}\right)$ & 30 \\
\hline \multicolumn{2}{|l|}{ Methanation Unit } \\
\hline Pressure (bar) & 10 \\
\hline $\mathrm{H}_{2} / \mathrm{CO}_{2}(\mathrm{~mol} / \mathrm{mol})$ & 4 \\
\hline Recycle ratio to MR1 & 0.70 \\
\hline Recycle ratio from SPT1 to MIX3 & 0.30 \\
\hline Recycle ratio from SPT2 to MIX3 & 0.57 \\
\hline MR1 in/out temperature $\left({ }^{\circ} \mathrm{C}\right)$ & $300 / 585$ \\
\hline MR2 in/out temperature $\left({ }^{\circ} \mathrm{C}\right)$ & $300 / 468$ \\
\hline MR3 in/out temperature $\left({ }^{\circ} \mathrm{C}\right)$ & $350 / 409$ \\
\hline MR4 in/out temperature $\left({ }^{\circ} \mathrm{C}\right)$ & $350 / 365$ \\
\hline Recycle blower (C2) isentropic efficiency (\%) & 85 \\
\hline
\end{tabular}


Table 1. Cont.

\begin{tabular}{cc}
\hline Plant Sections and Components & \\
\hline SNG Upgrading Unit & \\
\hline Dehydration membrane efficiency (\%) & 90 \\
$\mathrm{H}_{2}$ separation membrane efficiency (\%) & 90 \\
SNG compressor (C3) pressure ratio & 1.75 \\
$\mathrm{H}_{2}$ recycle compressor (C4) pressure ratio & 10 \\
Isentropic efficiency (\%) & 85 \\
\hline
\end{tabular}

In Table 2, the mass and energy balances under nominal conditions are reported. The composition of the produced SNG is $92.5 \% \mathrm{~mol} \mathrm{CH}_{4}, 2.2 \% \mathrm{~mol} \mathrm{H}_{2}, 5.3 \% \mathrm{~mol} \mathrm{CO}_{2}$ and traces of $\mathrm{H}_{2} \mathrm{O}$, and its lower heating value (LHV) is $43.4 \mathrm{MJ} / \mathrm{kg}$, whereas the calculated Wobbe Index is $43.9 \mathrm{MJ} / \mathrm{Nm}^{3}$. This value fits with the quality foreseen by the ongoing work on European standardisation of power-to-hydrogen applications, for which most of the European natural gas infrastructure can withstand a volume concentration $10 \%$ of hydrogen. The SNG production is equal to $38.52 \mathrm{~kg} / \mathrm{h}$ while the maximum amount of the stored hydrogen is $110 \mathrm{~kg}$. By considering the storage conditions ( $45 \mathrm{bar}$ and $30{ }^{\circ} \mathrm{C}$ ), the tank capacity is $30 \mathrm{~m}^{3}$. The PtSNG plant efficiency on an LHV basis is $43.9 \%$.

Table 2. Mass and energy balances under nominal conditions.

\begin{tabular}{|c|c|}
\hline $\begin{array}{l}\text { PtSNG Plant Capacity (Electrical Power Input) } \\
\qquad\left(\mathrm{MW}_{\mathrm{DC}}\right)\end{array}$ & $1 \mathrm{MW}$ \\
\hline Wind Energy supply $\left(\mathrm{kW}_{\mathrm{AC}}\right)$ & 1051 \\
\hline \multicolumn{2}{|l|}{ Plant Sections and Components } \\
\hline \multicolumn{2}{|l|}{ Water Pump (P1) } \\
\hline Water pump power consumption (kW) & 0.11 \\
\hline \multicolumn{2}{|l|}{ PEM Electrolysis Unit } \\
\hline Number of power modules & 1 \\
\hline $\mathrm{H}_{2} \mathrm{O}$ consumption $(\mathrm{kg} / \mathrm{h})$ & 150.3 \\
\hline $\mathrm{H}_{2}$ production $(\mathrm{kg} / \mathrm{h})$ & 16.8 \\
\hline Thermal power consumption $(\mathrm{kW})$ & 5.96 \\
\hline Electric power consumption $\left(\mathrm{kW}_{\mathrm{DC}}\right)$ & 998.9 \\
\hline \multicolumn{2}{|l|}{$\mathrm{H}_{2}$ Compressor $(\mathrm{C} 1)$} \\
\hline Compressor power consumption $(\mathrm{kW})$ & 7.74 \\
\hline \multicolumn{2}{|l|}{$\mathrm{H}_{2}$ Storage Unit } \\
\hline Storage capacity $\left(\mathrm{kg}\right.$ of $\left.\mathrm{H}_{2}\right)$ & 110 \\
\hline Storage volume $\left(\mathrm{m}^{3}\right)$ at $30^{\circ} \mathrm{C}$ & 30 \\
\hline \multicolumn{2}{|l|}{ Methanation Unit } \\
\hline Carbon dioxide mass flow $(\mathrm{kg} / \mathrm{h})$ & 96.8 \\
\hline $\mathrm{H}_{2}$ mass flow $(\mathrm{kg} / \mathrm{h})$ & 17.74 \\
\hline $\mathrm{H}_{2}$ recycle mass flow $(\mathrm{kg} / \mathrm{h})$ & 0.912 \\
\hline Recycle blower (C2) power consumption (kW) & 0.34 \\
\hline Raw SNG composition (mol \%) & $76.7 \mathrm{CH}_{4}, 18.5 \mathrm{H}_{2}, 4.4 \mathrm{CO}_{2}, 0.3 \mathrm{H}_{2} \mathrm{O}$ \\
\hline \multicolumn{2}{|l|}{ SNG upgrading } \\
\hline SNG compressor (C3) power consumption $(\mathrm{kW})$ & 3.05 \\
\hline $\mathrm{H}_{2}$ recycle compressor $(\mathrm{C} 4)$ power consumption $(\mathrm{kW})$ & 1.08 \\
\hline
\end{tabular}


Table 2. Cont.

\begin{tabular}{cc}
\hline $\begin{array}{c}\text { PtSNG Plant Capacity (Electrical Power Input) } \\
\left(\mathbf{M W}_{\mathbf{D C}}\right)\end{array}$ & $\mathbf{1} \mathbf{M W}$ \\
\hline Plant Performances & \\
\hline SNG production $(\mathrm{kg} / \mathrm{h})$ & 38.52 \\
SNG composition (mol \%) & $43.4 / 48.2$ \\
SNG LHV $/ \mathrm{HHV}$ basis $(\mathrm{MJ} / \mathrm{kg})$ & $30.5 / 33.9$ \\
SNG LHV $/ \mathrm{HHV}\left(\mathrm{MJ} / \mathrm{Nm}^{3}\right)$ & $43.9 / 48.8$ \\
\hline
\end{tabular}

Table 3 reports the thermal powers recoverable from the methanation unit and the flash unit as well as the range of temperature at which they are available. It is worth nothing that, due to the water condensation, a large amount of heat is available in the flash unit, albeit at a low temperature. In heat exchanger MHE4, the thermal energy is available at relatively low temperature levels compared to the other ones (the temperature level increases towards MHE1).

Table 3. Thermal powers available from the methanation unit and SNG inlet and outlet temperatures in the heat exchangers.

\begin{tabular}{cccccc}
\hline & MHE1 & MHE2 & MHE3 & MHE4 & FLASH \\
\hline $\mathrm{Q}(\mathrm{kW})$ & 58.1 & 9.9 & 4.8 & 15.8 & 59.1 \\
$\mathrm{~T}_{\text {in }}\left({ }^{\circ} \mathrm{C}\right)$ & 585 & 468 & 409 & 365 & 158 \\
$\mathrm{~T}_{\text {out }}\left({ }^{\circ} \mathrm{C}\right)$ & 300 & 350 & 350 & 158 & 25 \\
\hline
\end{tabular}

Thus, considering these temperature levels, the commercial Therminol-VP1, a diathermic oil capable of operating at high temperatures (up to $400^{\circ} \mathrm{C}$ ), has been chosen as heat transfer fluid for both the proposed heat recovery systems. The oil is maintained at a pressure of 10 bar to allow its operation at high temperatures while preventing the formation of vapours.

Finally, the plant operation time is listed in Table 4.

Table 4. Annual operation time of the $1 \mathrm{MW}$ PtSNG plant.

\begin{tabular}{cc}
\hline Operation time (hours) & 6047 \\
\hline Full load (hours) & 2500 \\
\hline Partial load (hours) & 3547 \\
\hline Standby (hours) & 2255 \\
\hline Transient (hours) & 458 \\
\hline
\end{tabular}

\subsection{Thermal Energy Requirement}

The reactors are multitube type and are insulated by means of a microporous material with reinforcing filaments in pyrogenic silica (Steelflex- $1100^{\circledR}$ ) with a thermal conductivity at $300{ }^{\circ} \mathrm{C}$ of about $0.035 \mathrm{~W} / \mathrm{m} \cdot \mathrm{K}$ and a thickness of $2 \mathrm{~cm}$.

Table 5 reports the thermal energy requirement $(\mathrm{kWh} / \mathrm{h})$ during the hot-standby and the thermal energy $(\mathrm{kWh})$ required to restart the reactors after the cold-standby. The thermal energy required during the hot-standby has been calculated by assuming a minimum working temperature of $250^{\circ} \mathrm{C}$ for each reactor (the minimum temperature for catalysts activation), while the thermal energy required to warm up the reactors after cold-standby, up to the catalysts' activation temperature, has been calculated by assuming $20^{\circ} \mathrm{C}$ as the reference ambient temperature. 
Table 5. Thermal energy requirements of the methanation unit.

\begin{tabular}{cccccc}
\hline & MHE1 & MHE2 & MHE3 & MHE4 & Total \\
\hline Hot-standby $(\mathrm{kWh} / \mathrm{h})$ & 1.01 & 0.74 & 0.74 & 0.56 & 3.06 \\
Cold-standby $(\mathrm{kWh})$ & 7.78 & 4.60 & 3.18 & 1.94 & 17.79 \\
\hline
\end{tabular}

By comparing the total energy requirement of the two standby options due to reactors' characteristics, it can be noted that if no heat recovery system is coupled to the plant, hot-standby is cheaper than cold-standby if its duration is less than six consecutive hours. In this case, the energy consumption would be covered by energy coming from outside the plant, representing a cost. Furthermore, hot-standby is preferable to avoid thermal stress and for reasons of flexibility, i.e., for restarting SNG production as soon as conditions return favourable [23]. Moreover, it is clear that the amount of energy that has to be stored in the storage devices (the oil tanks in the case of the thermal storage configuration and the batteries in the case of electrical storage configuration) depends on the number of hotstandby hours, with the thermal energy $(17.79 \mathrm{kWh})$ required to restart the methanation unit from cold-standby being fixed.

Thus, in order to identify the optimum combination between hot- and cold-standby hours when the plant is coupled with energy recovery systems, statistical analysis on the plant standby hours distribution is carried out in terms of the average duration and frequency. It is worth noting that this analysis is site-specific and closely linked to the typical annual wind energy profile of the considered RES facility, therefore tailor-made considerations would be required for other plants. Figure 6 shows the distribution of the standby periods in terms of the duration and frequency in the year.

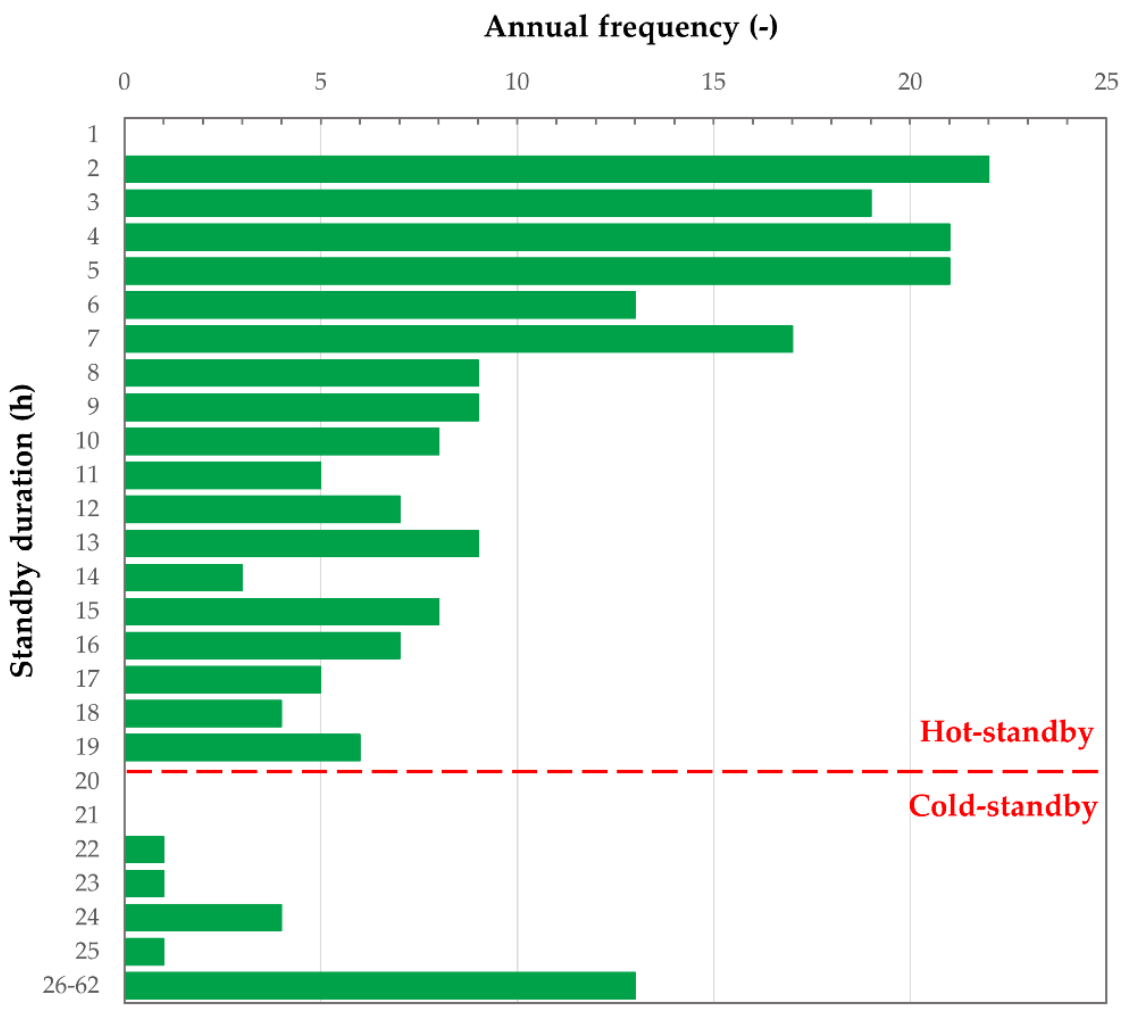

Figure 6. Results of the statistical analysis and distribution of the standby periods.

It can be noted that most of the standby periods have a duration less than $20 \mathrm{~h}$ and few occurrences have longer standby durations (the maximum is $62 \mathrm{~h}$ ). By designing the energy storage in an appropriate way, it is possible to extend the hot-standby duration without requiring any additional external energy. Although extending the hot standby for 
a greater number of hours results in higher energy consumption, in this case, the latter is covered with recovered waste energy, therefore it does not represent an operational cost. Thus, the duration of the standby periods and their frequency allow one to identify a threshold value for the maximum desirable duration of the hot-standby also useful for storage sizing. Beyond this threshold value, the control strategy switches the operation mode of the methanation unit to cold-standby. In this case, when the plant is coupled with heat recovery systems, the selected threshold value is $19 \mathrm{~h}$, as reported in Table 6 that summarises the results of the statistical analysis.

Table 6. Results of the statistical analysis and distribution of the standby periods.

\begin{tabular}{cc}
\hline Total number of methanation unit standby hours $(\mathrm{h})$ & 2255 \\
\hline Longest standby $(\mathrm{h})$ & 62 \\
\hline Total number of standby periods & 213 \\
\hline Average annual standby duration $(\mathrm{h})$ & 10.6 \\
\hline Threshold value $(\mathrm{h})$ & 19 \\
\hline Number of hot-standby & 193 \\
\hline Total hours of hot-standby $(\mathrm{h})$ & 1521 \\
\hline Number of cold-standby & 20 \\
\hline Total hours of cold-standby $(\mathrm{h})$ & 734 \\
\hline
\end{tabular}

Finally, according to the data reported in Table 5, the total energy that has to be stored in the storage devices is equal to $75.9 \mathrm{kWh}$ ( $58.1 \mathrm{kWh}$ to cover the energy consumption of the $19 \mathrm{~h}$ hot-standby and $17.8 \mathrm{kWh}$ to cover the energy consumption related to the restart from the cold-standby).

\subsubsection{Thermal Storage Results}

Results of the thermal storage model show that the hydrogen flow rate needed to maintain the temperature of the methanation reactors at least at the minimum catalysts activation temperature $\left(250^{\circ} \mathrm{C}\right)$ is equal to $6.5 \mathrm{~kg} / \mathrm{h}$ and its temperature at the inlet of the first reactor (MR1) is equal to $367^{\circ} \mathrm{C}$. The temperature of the hydrogen exiting the last reactor (MR4) is $250{ }^{\circ} \mathrm{C}$ (stream 15HR in Figure 3). Then, in order to ensure the cyclic operation, the hydrogen is re-heated by the diathermic oil from the hot oil tank (in the heat exchanger HRHE1) up to $367^{\circ} \mathrm{C}$.

With reference to the two-tank oil circuit, the hot oil flow (8HR) is equal to $31.5 \mathrm{~kg} / \mathrm{h}$ and it is stored at $387^{\circ} \mathrm{C}$. Because the diathermic oil leaves the HRHE1 heat exchanger at $281{ }^{\circ} \mathrm{C}$, it has to be cooled down to the storage temperature of the cold oil tank $\left(30^{\circ} \mathrm{C}\right)$. This cooling heat (from the HRHE2) can be further recovered for external or internal use.

The mass of diathermic oil necessary to store the required thermal energy $(75.9 \mathrm{kWh})$ is equal to $1067.3 \mathrm{~kg}$ (the specific heat is $2.416 \mathrm{~kJ} / \mathrm{kg} \cdot \mathrm{K}$ ) and the hot oil tank volume results in $1.50 \mathrm{~m}^{3}$ (the density at $387^{\circ} \mathrm{C}$ is $713.2 \mathrm{~kg} / \mathrm{m}^{3}$ ).

\subsubsection{Electrical Storage Results}

The ORC operating parameters have been chosen in order to maximise the waste heat recovery and the ORC efficiency. These constraints are conflicting. In fact, to maximise the waste heat recovery, a high flow rate of diathermic oil is required due to a large amount of heat available from the flash unit, while a high turbine inlet temperature, necessary for a high ORC efficiency, cannot be reached due to the temperature of the hot oil, which decreases as its flow rate increases.

Therefore, a compromise has been found by assuming an oil flow rate equal to $827 \mathrm{~kg} / \mathrm{h}$. The temperature of the hot oil exiting the last heat exchanger is about $300{ }^{\circ} \mathrm{C}$. 
Figure 7 shows the energy balance of the oil circuit. The total amount of waste heat recovered and supplied to the ORC is therefore equal to $145.2 \mathrm{~kW}$, out of a total of $148 \mathrm{~kW}$ that was recoverable from the methanation unit.

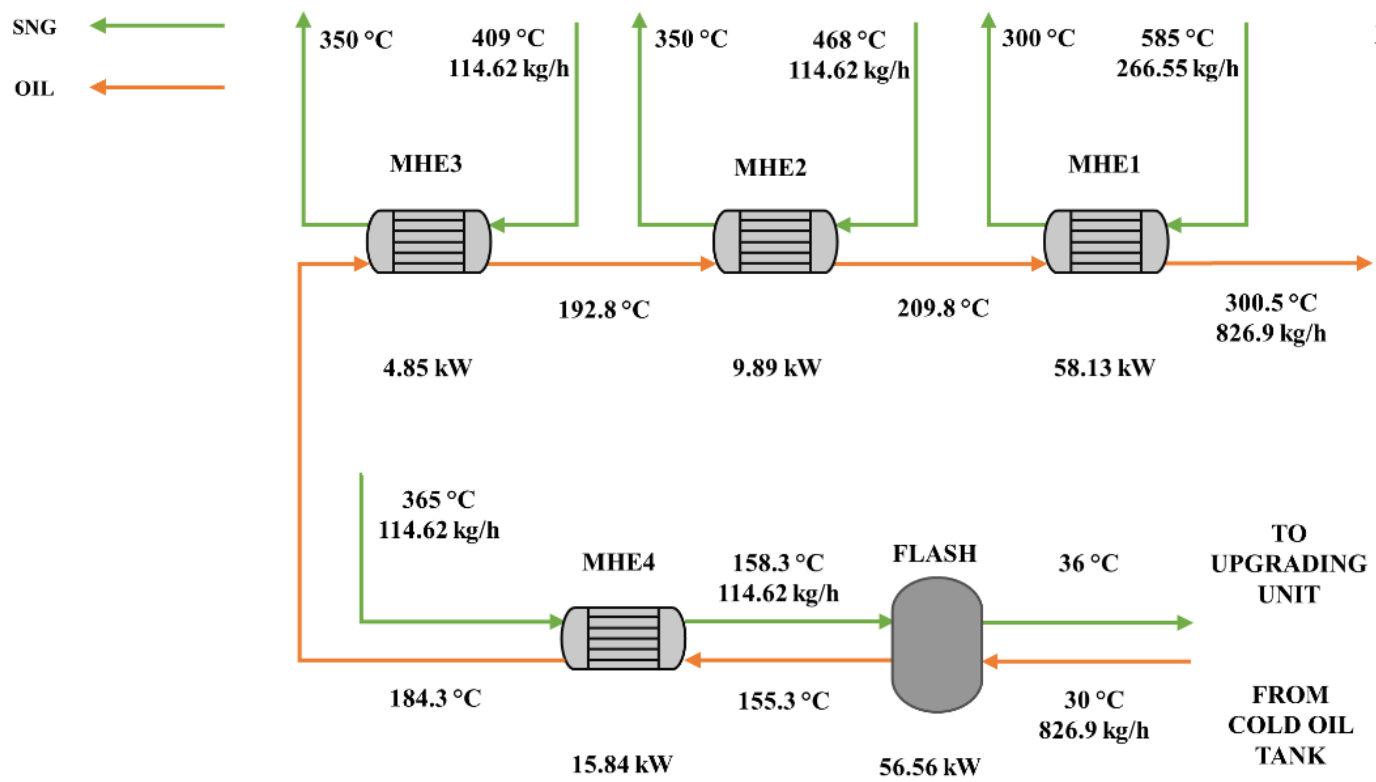

Figure 7. Diathermic oil circuit for waste heat recovery from the methanation unit, sized for coupling with the ORC power unit.

With respect to the operating parameters of the ORC cycle, the minimum and maximum pressures and the inlet turbine temperature are set to 3 bar, 30 bar and $183^{\circ} \mathrm{C}$, respectively.

Table 7 summarises the main operating conditions and performance of the ORC unit. Detailed results concerning streams' temperatures, pressures and flow rates are also given in Figure 8.

Table 7. Operating conditions and performance of the ORC unit.

\begin{tabular}{cc}
\hline ORC Operating Parameter & \\
\hline Isobutane flow rate $(\mathrm{kg} / \mathrm{h})$ & 1200 \\
Condenser pressure $(\mathrm{bar})$ & 3 \\
Pressure ratio & 10 \\
Turbine inlet temperature $\left({ }^{\circ} \mathrm{C}\right)$ & 183 \\
Split to ECO $(\mathrm{kg} / \mathrm{h})$ & 499.6 \\
Pump efficiency & 0.70 \\
Scroll expander efficiency & 0.65 \\
\hline ORC Performance & \\
\hline Compression power $(\mathrm{kW})$ & 2.47 \\
Expansion power $(\mathrm{kW})$ & 26.57 \\
Net mechanical power $(\mathrm{kW})$ & 24.1 \\
Provided heat power $(\mathrm{kW})$ & 145.2 \\
Overall ORC efficiency $(\%)$ & 16.6 \\
\hline
\end{tabular}




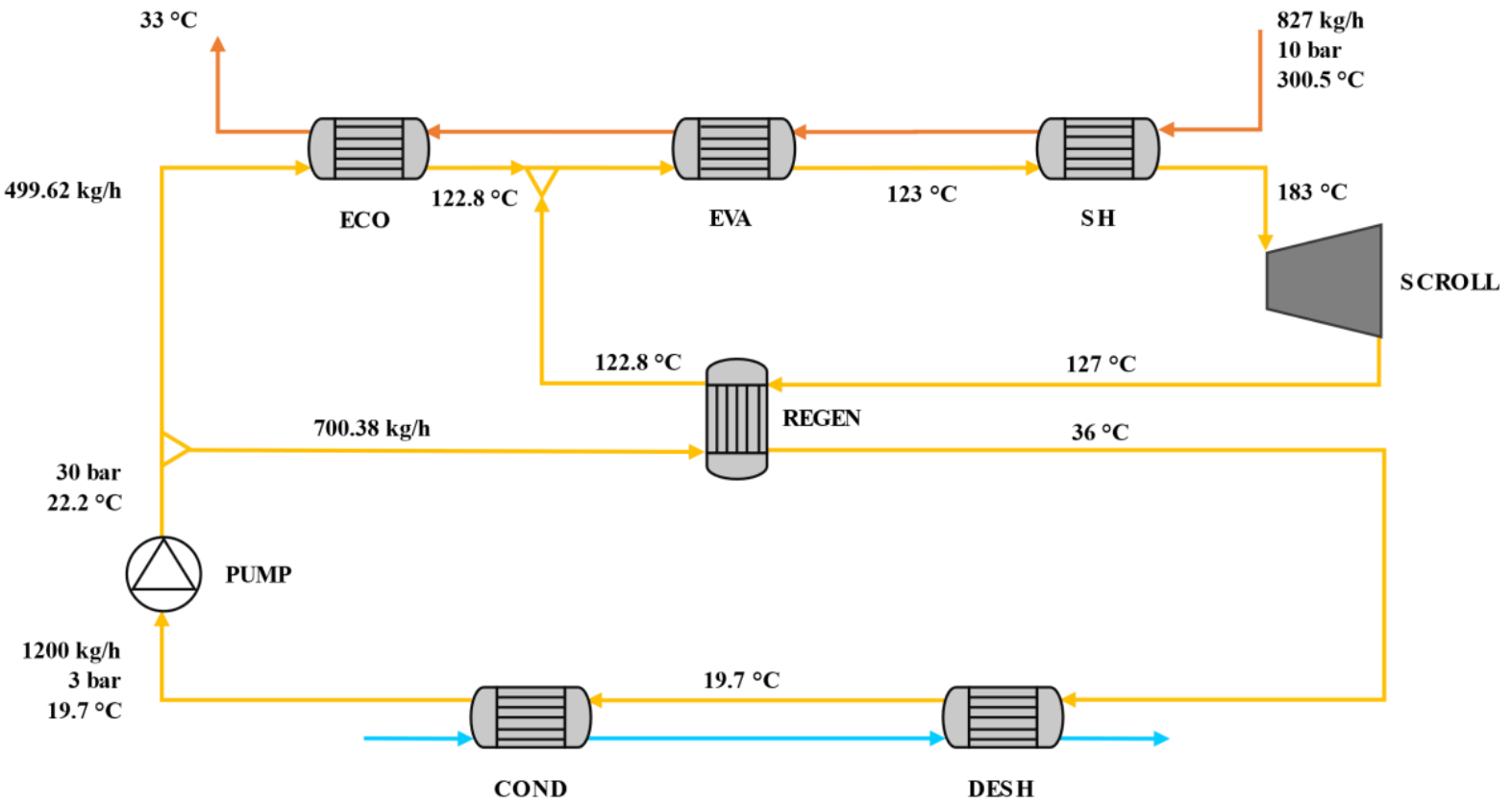

Figure 8. Results for the ORC power unit.

Regarding the size of the oil tanks necessary to decouple the heat recovery from the electricity generation allowing more continuous operation of the ORC, the thermal energy stored is $435.6 \mathrm{kWh}$ ( $3 \mathrm{~h}$ of operation in full load). Therefore, $2481 \mathrm{~kg}$ of diathermic oil is stored at $300{ }^{\circ} \mathrm{C}$. Since the diathermic oil density at $300{ }^{\circ} \mathrm{C}$ is $817 \mathrm{~kg} / \mathrm{m}^{3}$, the volume of the hot oil tank results equal approximately $3 \mathrm{~m}^{3}$.

Referring to the battery sizing, by assuming an electrical efficiency equal to 0.95 , the battery is designed for a capacity of $80 \mathrm{kWh}$. When the methanation unit is in operation and the ORC produces electrical energy, part of this is used for plant auxiliaries ( $12.3 \mathrm{kWh}$ at full load operation for $1 \mathrm{~h}$ ) so that the electrical energy useful to charge the batteries is equal to $11.8 \mathrm{kWh}$, resulting in a battery charge time of $6.8 \mathrm{~h}$.

\subsection{Annual Performances Results}

Table 8 reports the annual energy balance as well as the annual performances of the PtSNG plant. The annual water, hydrogen and carbon dioxide consumptions are equal to $790 \mathrm{Nm}^{3}, 999,000 \mathrm{Nm}^{3}$ and $261,286 \mathrm{Nm}^{3}$, respectively. The SNG production is equal to $265,287 \mathrm{Nm}^{3}$.

Table 8. Annual mass and energy balance and annual performances.

\begin{tabular}{cc}
\hline PtSNG Plant Capacity (Electrical Power Input DC) & 1 MW \\
\hline Energy (MWh/year) & $5483 / 5209$ \\
\hline Annual electric energy consumption of the electrolysis unit (AC/DC) & 29.8 \\
Annual electric energy consumption for compressors and auxiliaries & 4.7 \\
Annual energy consumption for hot-standby & 0.36 \\
Annual energy consumption for cold-standby & 2424 \\
Annual SNG chemical energy (LHV basis) & 3.6 \\
Chemical energy of the remaining hydrogen * (LHV basis) & Thermal storage \\
\hline Plant Performances & 44.0 \\
\hline PtSNG Plant annual efficiency, LHV basis (\%) & 48.9 \\
PtSNG Plant annual efficiency, HHV basis (\%) & 44.3 \\
\hline
\end{tabular}

* The remaining hydrogen in the storage tank is the difference between the annual hydrogen production and the annual hydrogen consumption. 
From the data in Table 8 , it can be noted that the energy consumption for hot and cold standby states (5.06 MWh/year in total) is only a small percentage $(0.09 \%)$ of the total energy required to operate the plant (electric energy in $\mathrm{AC}$ for the electrolyser and that for ancillary equipment).

As regards the annual efficiencies, the PtSNG plant in the base case, without any heat recovery systems, shows efficiencies of $43.9 \%$ on an LHV basis and $48.8 \%$ on an HHV basis. The results for the thermal storage and electrical storage configurations show that the energy recovery intended to satisfy internal consumption only is beneficial for a PtSNG plant, albeit slightly. Compared to the base case (in which no energy recovery is carried out), the increase in the annual efficiency was proportional to the annual energy savings achieved by the two proposed systems, equal to $5.06 \mathrm{MWh} /$ year and $34.86 \mathrm{MWh} /$ year for the thermal storage and the electrical storage, respectively. In the base case, it would be reasonable to expect a decrease in the annual efficiency with respect to the nominal efficiency, due to shutdowns and the fluctuating plant behaviour. However, the annual efficiency remains close to the nominal efficiency values in the case in which waste energy is recovered for internal uses. Moreover, the electrical storage configuration shows a slightly higher annual efficiency with respect to the thermal storage configuration because in the first case, the ancillary equipment power consumption is also satisfied by the waste energy recovered. If the surplus electricity produced by the ORC was also valued or sold externally, slightly higher annual efficiencies could be achieved.

A rough discussion on costs is also given. In principle, the proposed energy recovery systems should have very low operating expenditures, linked mainly to their maintenance as they are operated with waste energy, while the capital costs should be carefully evaluated. This will be the subject of future investigation in greater detail. Capital expenditures are expected to be low in the case of thermal storage (purchase of diathermic oil tanks and heat transfer fluid), and higher in the case of electrical storage (higher volumes of diathermic oil, ORC and batteries). However, electrical storage could lead to greater annual savings, avoiding the expense of electricity supplied to ancillary equipment, and providing a faster return on investment. In reality, considering the heat recovery only to satisfy the internal demands of the plant is probably not convenient, but it can become interesting if one considers the possibility of being able to sell all the recoverable waste energy, whether it is heat (for example for district heating) or electricity that can be sold to the grid. Meeting the internal energy demand of the plant with recovered waste energy could also lead to environmental benefits, where previously the additional external energy was provided by the electric grid (affected by the energy mix) or by natural gas.

Finally, it is emphasised that in this work, the heat recovery systems have been designed only to ensure the self-sustenance of the plant regarding the standby periods and ancillary equipment energy requirements. However, the plant internal energy consumption is significantly lower than the waste energy available from the methanation process. A remarkable further improvement of the PtSNG plant performance can be reached if this surplus is employed for external thermal or electrical utilities.

\section{Conclusions}

In this study, two heat recovery systems for a $1 \mathrm{MW}$ (the DC wind power to the electrolysis unit) PtSNG plant coupled with a $12 \mathrm{MW}$ wind farm have been presented. The common approach is based on the valorisation of the waste heat generated during the plant operation to self-sustain, from an energetic point of view, the standby conditions (hot-standby and cold-standby).

In the first one (thermal storage configuration), the recovered thermal energy is used to satisfy the thermal energy demand of the reactors during the standby periods by means of a thermal carrier (hydrogen).

In the second one (electrical storage configuration), the stored thermal energy is used to produce electricity by means of an Organic Rankine Cycle (ORC) where iso-butane is used as the working fluid. This electrical energy is then stored in batteries, and it is used to 
meet the energy requirements of the electrical trace heating system of the methanation unit during the standby periods.

The analysis has been performed by means of thermochemical and electrochemical models developed in the Aspen Plus environment to define the mass and energy balances in steady-state conditions and integrated with a dynamic model built in the Matlab language to forecast the plant operation time and the annual performance.

The main constraint for the thermal recovery systems sizing is the minimisation of the storage devices (oil tanks for the thermal storage configuration or batteries for the electrical storage configuration) achieved by identifying the optimum combination between the hot- and cold-standby hours. To this end, statistical analysis of the plant standby hours distribution in terms of the average duration and frequency has been carried out. For the specific energy input profile, the maximum duration of the hot standby has been found equal to $19 \mathrm{~h}$.

Results of the thermal storage configuration have shown that the hydrogen flow rate needed to maintain the methanation reactors at the minimum catalyst temperature $\left(250{ }^{\circ} \mathrm{C}\right)$ is equal to $6.5 \mathrm{~kg} / \mathrm{h}$ at $367^{\circ} \mathrm{C}$, while the hot oil flow rate required to heat the hydrogen is equal to $31.5 \mathrm{~kg} / \mathrm{h}$ and is stored at $387^{\circ} \mathrm{C}$.

Results of the electric storage configuration have shown that the electric power generated is equal to $24 \mathrm{~kW}$ and the ORC cycle efficiency is $16.6 \%$. The battery is sized for a capacity of $80 \mathrm{kWh}$, guaranteeing $19 \mathrm{~h}$ of hot standby and a cold restart by means of electrical trace heating. When the methanation unit is in operation and the ORC produces electrical energy, part of this is used for plant auxiliaries $(12.3 \mathrm{kWh}$ at full-load operation for $1 \mathrm{~h}$ ), so the electrical energy useful to charge the battery is equal to $11.8 \mathrm{kWh}$, resulting in a battery charge time of $6.8 \mathrm{~h}$.

The overall nominal efficiencies obtained for the PtSNG plant are equal to $43.9 \%$ and $48.8 \%$ on LHV and HHV bases, respectively. When heat recovery systems are coupled to the plant, the annual efficiencies on an LHV basis have been found to be $44.0 \%$ and $44.3 \%$ for the thermal storage and electrical storage configurations, respectively. The results showed that the internal heat recovery system positively impacted the annual efficiency. It is expected that this could lead to a decrease in the plant operational costs with an associated relatively low initial capital expenditure. Furthermore, the amount of waste heat recoverable from the methanation unit resulted in being significantly higher than the energy needed for the self-sustainment of the plant. Therefore, to achieve a considerable increase in the efficiency of the plant, it is necessary to couple the plant with other thermal or electrical utilises (e.g., district heating, cogeneration of SNG and power, etc.). In the event that a decision is made to carry out cogeneration of electricity to sell it to the grid, this could also be produced with more efficient systems than the ORC (e.g., steam turbine), but careful cost assessments are required both on initial investments and on possible revenues.

Author Contributions: Conceptualization, A.P. and G.S.; methodology, A.P. and G.S.; software, D.C. and L.M.; validation, D.C. and L.M.; formal analysis A.P., D.C. and L.M.; investigation, G.S., D.C. and L.M.; resources, A.P. and G.S.; data curation A.P., D.C. and G.S.; writing-original draft preparation, D.C. and L.M.; writing-review and editing, A.P. and G.S.; visualization, G.S.; supervision, A.P.; project administration, A.P. and G.S.; funding acquisition, A.P. and G.S. All authors have read and agreed to the published version of the manuscript.

Funding: This research was supported by Regione Lazio, Progetti Strategici 2019 Progetto SINBIO "Sistemi INtegrati di produzione e immissione in rete di BIOmetano e gas sintetici da fonti rinnovabili", Grant number F82I20000300002.

Conflicts of Interest: The authors declare no conflict of interest.

\section{Appendix A}

\section{Methanation Unit Modelling}

The methanation unit has been modelled by using Aspen Plus software. The flowsheet of the model is shown in Figure A1. Adiabatic Plug Flow Reactor (PFR) blocks have been 
used to simulate the methanation process. The thermodynamic and transport properties of the components are calculated using the RKSMHV2 property method. This property method, based on the Redlich-Kwong-Soave equation of state with modified Huron-Vidal mixing rules, is used for mixtures of non-polar and polar compounds, in combination with light gases.

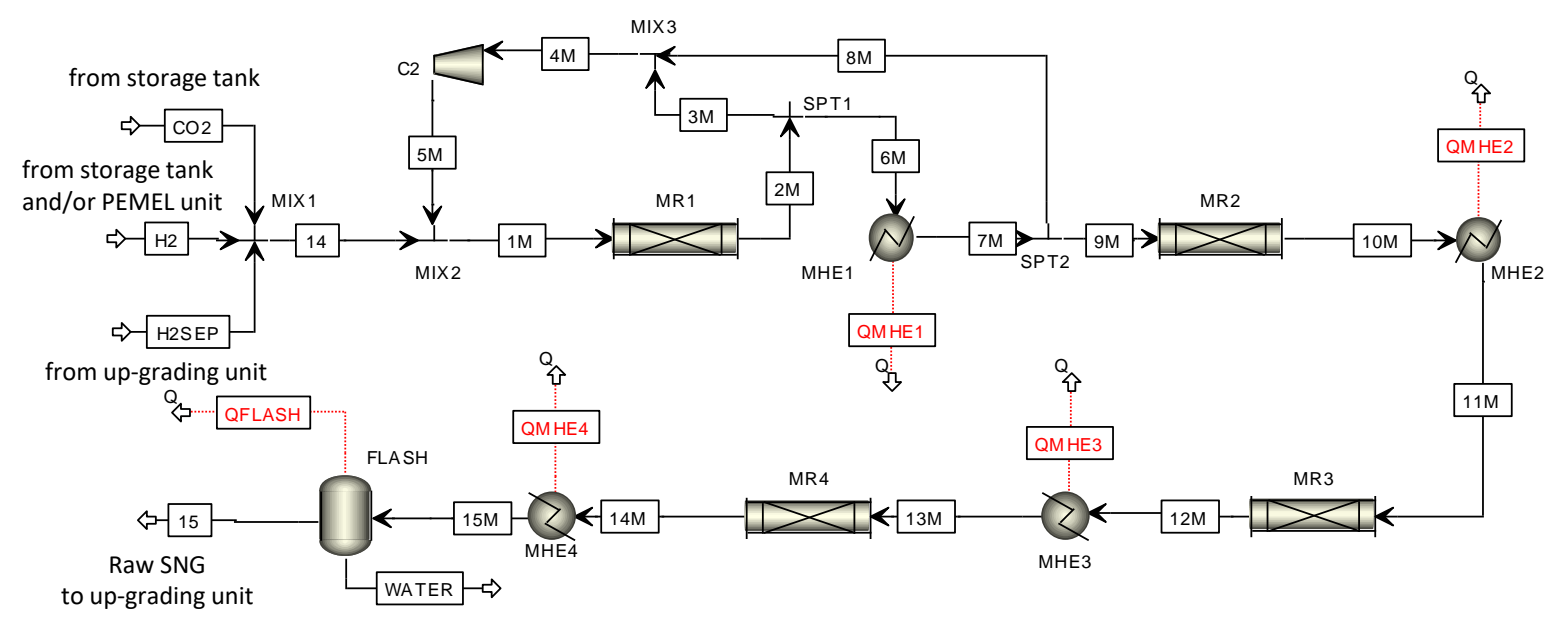

Figure A1. Flowsheet of the $\mathrm{CO}_{2}$ methanation unit.

The kinetic model developed by $\mathrm{Xu}$ and Froment has been applied to calculate the catalytic reaction rates as in [18].

The following three reaction are considered:

\section{CO methanation :}

$$
\mathrm{CO}+3 \mathrm{H}_{2} \rightarrow \mathrm{CH}_{4}+\mathrm{H}_{2} \mathrm{O} \quad \Delta H_{298}^{0}=-206 \mathrm{~kJ} / \mathrm{mol}
$$

$\mathrm{CO}_{2}$ methanation :

$$
\mathrm{CO}_{2}+4 \mathrm{H}_{2} \rightarrow \mathrm{CH}_{4}+2 \mathrm{H}_{2} \mathrm{O} \quad \Delta H_{298}^{0}=-165 \mathrm{~kJ} / \mathrm{mol}
$$

Water gas shift :

$$
\mathrm{CO}_{2}+\mathrm{H}_{2} \rightarrow \mathrm{CH}_{4}+\mathrm{H}_{2} \mathrm{O} \quad \Delta H_{298}^{0}=+41 \mathrm{~kJ} / \mathrm{mol}
$$

The corresponding rate equations are given by the equations below, whose kinetic parameter values are summarized in Table A1.

CO methanation :

$$
r_{1}=\frac{k_{1}}{p_{\mathrm{H}_{2}}^{2.5}} \cdot \frac{p_{\mathrm{CH}_{4}} \cdot p_{\mathrm{H}_{2} \mathrm{O}}-\frac{p_{\mathrm{H}_{2}}^{3} \cdot p_{\mathrm{CO}}}{K_{1}}}{D E N^{2}}
$$

$\mathrm{CO}_{2}$ methanation :

$$
r_{2}=\frac{k_{2}}{p_{\mathrm{H}_{2}}^{3.5}} \cdot \frac{p_{\mathrm{CO}} \cdot p_{\mathrm{H}_{2} \mathrm{O}}^{2}-\frac{p_{\mathrm{H}_{2}}^{4} \cdot p_{\mathrm{CO}_{2}}}{K_{2}}}{D E N^{2}}
$$

Water gas shift :

$$
r_{3}=\frac{k_{3}}{p_{\mathrm{H}_{2}}} \cdot \frac{p_{\mathrm{CO}} \cdot p_{\mathrm{H}_{2} \mathrm{O}}-\frac{p_{\mathrm{H}_{2}} \cdot p_{\mathrm{CO}_{2}}}{K_{3}}}{D E N^{2}}
$$


where:

$$
D E N=1+K_{\mathrm{CO}} p_{\mathrm{CO}}+K_{\mathrm{H}_{2}} p_{\mathrm{H}_{2}}+K_{\mathrm{CH}_{4}} p_{\mathrm{CH}_{4}}+\frac{K_{\mathrm{H}_{2} \mathrm{O}} p_{\mathrm{H}_{2} \mathrm{O}}}{p_{\mathrm{H}_{2}}}
$$

The pre-exponential factors $\left(\boldsymbol{k}_{i}\right)$ and $A\left(\boldsymbol{K}_{j}\right)$ are determined from $\boldsymbol{k}_{\boldsymbol{i}, \boldsymbol{T}}$ and $\boldsymbol{K}_{j, T}$, while $\boldsymbol{E}_{\boldsymbol{i}}$ and $\Delta \boldsymbol{H}_{j}$ values can be calculated by the Arrhenius and van't Hoff equations:

$$
\begin{gathered}
k_{i}=A\left(k_{i, T}\right) \cdot \exp \left(\frac{-E_{i}}{R T}\right) \\
K_{i}=A\left(K_{i, T}\right) \cdot \exp \left(\frac{-\Delta H_{i}}{R T}\right) \\
K_{j}=A\left(K_{j, T}\right) \cdot \exp \left(\frac{-\Delta H_{j}}{R T}\right) \\
A\left(k_{i}\right)=k_{i, T} \cdot \exp \left(\frac{E_{i}}{R T}\right) \\
A\left(K_{j}\right)=K_{j, T} \cdot \exp \left(\frac{\Delta H_{j}}{R T}\right)
\end{gathered}
$$

where:

- $\quad i=1,2,3$ and $j=\mathrm{CH}_{4}, \mathrm{H}_{2} \mathrm{O}, \mathrm{CO}, \mathrm{H}_{2}$;

- $\quad k_{1}, k_{2}, k_{3}$ are the rate coefficient of Equations (A4)-(A6), respectively;

- $\quad K_{1}, K_{2}, K_{3}$ are the rate coefficient of Equations (A4)-(A6), respectively;

- $K_{\mathrm{CH}_{4}}, K_{\mathrm{CO}}, K_{\mathrm{H}_{2}}$ are the adsorption constants of reaction for $\mathrm{CH}_{4}, \mathrm{CO}$ and $\mathrm{H}_{2}$;

- $K_{\mathrm{H}_{2} \mathrm{O}}$ is the desorption constant of $\mathrm{H}_{2} \mathrm{O}$;

- $A\left(k_{i}\right)$ is pre-exponential factor of the rate coefficient, $k_{i}$;

\begin{tabular}{|c|c|}
\hline Parameter & Value \\
\hline$A\left(k_{1}\right), \mathrm{kmol} \mathrm{bar}^{1} \mathrm{~kg}_{\mathrm{cat}}{ }^{-1} \mathrm{~h}^{-1}$ & $4.225 \times 10^{15}$ \\
\hline$A\left(k_{2}\right), \mathrm{kmol} \mathrm{bar}^{1 / 2} \mathrm{~kg}_{\mathrm{cat}}{ }^{-1} \mathrm{~h}^{-1}$ & $1.020 \times 10^{15}$ \\
\hline$A\left(k_{3}\right), \mathrm{kmol} \mathrm{bar}^{1 / 2} \mathrm{~kg}_{\mathrm{cat}}{ }^{-1} \mathrm{~h}^{-1}$ & $1.955 \times 10^{6}$ \\
\hline$A\left(K_{\mathrm{CH}_{4}}\right)$, bar $^{-1}$ & $6.65 \times 10^{-4}$ \\
\hline$A\left(K_{\mathrm{H}_{2}}\right)$, bar $^{-1}$ & $6.12 \times 10^{-9}$ \\
\hline$A\left(K_{\mathrm{CO}}\right)$, bar $^{-1}$ & $8.23 \times 10^{-5}$ \\
\hline$A\left(K_{\mathrm{H}_{2} \mathrm{O}}\right)$ & $1.77 \times 10^{5}$ \\
\hline$A\left(K_{1}\right)$, bar $^{2}$ & $5.375 \times 10^{10}$ \\
\hline$A\left(K_{2}\right)$, bar $^{2}$ & $4.707 \times 10^{12}$ \\
\hline$A\left(K_{3}\right)$ & $1.142 \times 10^{-2}$ \\
\hline$E_{1}, \mathrm{~kJ} \mathrm{~mol}^{-1}$ & 240.1 \\
\hline$E_{2}, \mathrm{~kJ} \mathrm{~mol}^{-1}$ & 243.9 \\
\hline$E_{3}, \mathrm{~kJ} \mathrm{~mol}^{-1}$ & 67.13 \\
\hline$\Delta H_{1}, \mathrm{~kJ} \mathrm{~mol}^{-1}$ & -206.1 \\
\hline$\Delta \boldsymbol{H}_{2}, \mathrm{~kJ} \mathrm{~mol}^{-1}$ & -165.0 \\
\hline$\Delta H_{3}, \mathrm{~kJ} \mathrm{~mol}^{-1}$ & +41.15 \\
\hline$\Delta H_{\mathrm{CH}_{4}}, \mathrm{~kJ} \mathrm{~mol}^{-1}$ & -38.28 \\
\hline$\Delta \boldsymbol{H}_{\mathbf{H}_{2}}, \mathrm{~kJ} \mathrm{~mol}^{-1}$ & -82.90 \\
\hline$\Delta \boldsymbol{H}_{\mathrm{H}_{2} \mathbf{O}}, \mathrm{kJ} \mathrm{mol}^{-1}$ & 88.68 \\
\hline$\Delta H_{\mathrm{CO}}, \mathrm{kJ} \mathrm{mol}^{-1}$ & -70.65 \\
\hline
\end{tabular}

- $A\left(K_{j}\right)$ is pre-exponential factor of the rate coefficient, $K_{j}$;

- $\quad E_{i}$ is the activation energy of reaction $i$-th;

- $\Delta \boldsymbol{H}_{j}$ is the enthalpy change of reaction or adsorption;

- $\quad p$ is the partial pressure.

Table A1. Parameters of the reaction rate adapted from $\mathrm{Xu}$ and Froment [24]. 


\section{References}

1. European Commission. Communication from the Commission to the European Parliament, the Council, the European Economic and Social Committee and the Committee of the Regions Commission Work Programme 2017 Delivering a Europe That Protects, Empowers and Defends COM/2016/0710 Final 2019. Available online: https:/ / eur-lex.europa.eu/resource.html?uri=cellar: b828d165-1c22-11ea-8c1f-01aa75ed71a1.0006.02/DOC_1\&format=PDF (accessed on 31 August 2021).

2. Directive (EU) 2018/2001 of the European Parliament and of the Council of 11 December 2018 on the Promotion of the Use of Energy from Renewable Sources. Official Journal of the European Union, L328/82, Brussels, Belgium, 2018. Available online: https: / / eur-lex.europa.eu/legal-content/EN/TXT/PDF/?uri=CELEX:32018L2001\&from=EN (accessed on 15 October 2021).

3. European Green Deal: Commission Proposes Transformation of EU Economy and Society to Meet Climate Ambitions. Available online: https:/ / ec.europa.eu/commission/presscorner/detail/en/IP_21_3541 (accessed on 11 October 2021).

4. Wind Delivers the Energy Society Wants. Available online: https://windeurope.org/about-wind/wind-energy-today / (accessed on 11 October 2021).

5. Pinciroli, L.; Baraldi, P.; Ballabio, G.; Compare, M.; Zio, E. Deep Reinforcement Learning Based on Proximal Policy Optimization for the Maintenance of a Wind Farm with Multiple Crews. Energies 2021, 14, 6743. [CrossRef]

6. Ju, X.; Liu, F.; Wang, L.; Lee, W.-J. Wind Farm Layout Optimization Based on Support Vector Regression Guided Genetic Algorithm with Consideration of Participation among Landowners. Energy Convers. Manag. 2019, 196, 1267-1281. [CrossRef]

7. Mazza, A.; Bompard, E.; Chicco, G. Applications of Power to Gas Technologies in Emerging Electrical Systems. Renew. Sustain. Energy Rev. 2018, 92, 794-806. [CrossRef]

8. Götz, M.; Lefebvre, J.; Mörs, F.; McDaniel Koch, A.; Graf, F.; Bajohr, S.; Reimert, R.; Kolb, T. Renewable Power-to-Gas: A Technological and Economic Review. Renew. Energy 2016, 85, 1371-1390. [CrossRef]

9. Van Leeuwen, C.; Zauner, A. D8.3-Report on the Costs Involved with PtG Technologies and Their Potentials across the EU; EU Horizon 2020 Project STORE\&GO: Brussels, Belgium, 2018.

10. Frank, E.; Gorre, J.; Ruoss, F.; Friedl, M.J. Calculation and Analysis of Efficiencies and Annual Performances of Power-to-Gas Systems. Appl. Energy 2018, 218, 217-231. [CrossRef]

11. Schaaf, T.; Grünig, J.; Schuster, M.R.; Rothenfluh, T.; Orth, A. Methanation of $\mathrm{CO}_{2}$-Storage of Renewable Energy in a Gas Distribution System. Energ. Sustain. Soc. 2014, 4, 2. [CrossRef]

12. Application of Hydrogen by Use of Chemical Reactions of Hydrogen and Carbon Dioxide. In Science and Engineering of HydrogenBased Energy Technologies; Elsevier: Amsterdam, The Netherlands, 2019; pp. 279-289, ISBN 978-0-12-814251-6.

13. Sabatier, P.; Senderens, J.B. New Synthesis of Methane. Comptes Rendus Hebd. Des. Seances Acad. Des. Scrences 1902, 134, 514-516.

14. Buchholz, O.S.; van der Ham, A.G.J.; Veneman, R.; Brilman, D.W.F.; Kersten, S.R.A. Power-to-Gas: Storing Surplus Electrical Energy. A Design Study. Energy Procedia 2014, 63, 7993-8009. [CrossRef]

15. Anghilante, R.; Lefebvre, J. Coupling of a 3 Phase Methanation Reactor and a High Temperature Electrolyser Using Matlab Simulink. In Proceedings of the 11th European SOFC and SOE Forum 2014, Lucerne, Switzerland, 1 July 2014.

16. Giglio, E.; Lanzini, A.; Santarelli, M.; Leone, P. Synthetic Natural Gas via Integrated High-Temperature Electrolysis and Methanation: Part I-Energy Performance. J. Energy Storage 2015, 1, 22-37. [CrossRef]

17. Gruber, M.; Weinbrecht, P.; Biffar, L.; Harth, S.; Trimis, D.; Brabandt, J.; Posdziech, O.; Blumentritt, R. Power-to-Gas through Thermal Integration of High-Temperature Steam Electrolysis and Carbon Dioxide Methanation-Experimental Results. Fuel Process. Technol. 2018, 181, 61-74. [CrossRef]

18. Chauvy, R.; Dubois, L.; Lybaert, P.; Thomas, D.; De Weireld, G. Production of Synthetic Natural Gas from Industrial Carbon Dioxide. Appl. Energy 2020, 260, 114249. [CrossRef]

19. Perna, A.; Moretti, L.; Ficco, G.; Spazzafumo, G.; Canale, L.; Dell'Isola, M. SNG Generation via Power to Gas Technology: Plant Design and Annual Performance Assessment. Appl. Sci. 2020, 10, 8443. [CrossRef]

20. Gorre, J.; Ortloff, F.; van Leeuwen, C. Production Costs for Synthetic Methane in 2030 and 2050 of an Optimized Power-to-Gas Plant with Intermediate Hydrogen Storage. Appl. Energy 2019, 253, 113594. [CrossRef]

21. Fendt, S.; Buttler, A.; Gaderer, M.; Spliethoff, H. Comparison of Synthetic Natural Gas Production Pathways for the Storage of Renewable Energy: Comparison of Synthetic Natural Gas Production Pathways. WIREs Energy Environ. 2016, 5, 327-350. [CrossRef]

22. Salomone, F.; Giglio, E.; Ferrero, D.; Santarelli, M.; Pirone, R.; Bensaid, S. Techno-Economic Modelling of a Power-to-Gas System Based on SOEC Electrolysis and $\mathrm{CO}_{2}$ Methanation in a RES-Based Electric Grid. Chem. Eng. J. 2019, 377, 120233. [CrossRef]

23. Inkeri, E.; Tynjälä, T.; Karjunen, H. Significance of Methanation Reactor Dynamics on the Annual Efficiency of Power-to-Gas -System. Renew. Energy 2021, 163, 1113-1126. [CrossRef]

24. Xu, J.; Froment, G.F. Methane Steam Reforming, Methanation and Water-Gas Shift: I. Intrinsic Kinetics. AIChE J. 1989, 35, 88-96. [CrossRef] 